\title{
Anti-diabetic rosiglitazone remodels the adipocyte transcriptome by redistributing transcription to PPAR $\gamma$-driven enhancers
}

\author{
Sonia E. Step, ${ }^{1,2,3,4,8}$ Hee-Woong Lim ${ }^{4,5,8}$ Jill M. Marinis, ${ }^{1,2,4}$ Andreas Prokesch,,${ }^{1,2,4,6,7}$ \\ David J. Steger, ${ }^{1,2,4}$ Seo-Hee You, ${ }^{1,2,4}$ Kyoung-Jae Won, ${ }^{4,5}$ and Mitchell A. Lazar ${ }^{1,2,3,4,5,9}$ \\ ${ }^{1}$ Division of Endocrinology, Diabetes, and Metabolism, ${ }^{2}$ Department of Medicine, ${ }^{3}$ Department of Pharmacology, ${ }^{4}$ The Institute \\ for Diabetes, Obesity, and Metabolism, ${ }^{5}$ Department of Genetics, Perelman School of Medicine, University of Pennsylvania, \\ Philadelphia, Pennsylvania 19104, USA; ${ }^{6}$ Institute for Genomics and Bioinformatics, ${ }^{7}$ Institute of Biochemistry, Graz University \\ of Technology, Graz 8010, Austria
}

Rosiglitazone (rosi) is a powerful insulin sensitizer, but serious toxicities have curtailed its widespread clinical use. Rosi functions as a high-affinity ligand for peroxisome proliferator-activated receptor $\gamma(\operatorname{PPAR} \gamma)$, the adipocytepredominant nuclear receptor (NR). The classic model, involving binding of ligand to the NR on DNA, explains positive regulation of gene expression, but ligand-dependent repression is not well understood. We addressed this issue by studying the direct effects of rosi on gene transcription using global run-on sequencing (GRO-seq). Rosiinduced changes in gene body transcription were pronounced after $10 \mathrm{~min}$ and correlated with steady-state mRNA levels as well as with transcription at nearby enhancers (enhancer RNAs [eRNAs]). Up-regulated eRNAs occurred almost exclusively at PPAR $\gamma$-binding sites, to which rosi treatment recruited coactivators, including MED1, p300, and CBP. In contrast, transcriptional repression by rosi involved a loss of coactivators from eRNA sites devoid of PPAR $\gamma$ and enriched for other transcription factors, including AP-1 factors and C/EBPs. Thus, rosi activates and represses transcription by fundamentally different mechanisms that could inform the future development of antidiabetic drugs.

[Keywords: adipocyte; diabetes; rosiglitazone; transcription; PPAR $\gamma$; enhancer RNA]

Supplemental material is available for this article.

Received January 9, 2014; revised version accepted March 31, 2014.

Peroxisome proliferator-activated receptor $\gamma(\operatorname{PPAR} \gamma)$ is a nuclear receptor (NR) that is dramatically induced during adipogenesis and expressed predominantly in adipose tissue (Chawla and Lazar 1994; Tontonoz et al. 1994a). It is necessary (Rosen et al. 1999) and sufficient (Tontonoz et al. 1994b) for adipogenesis and is also critical for the functions of mature adipocytes, including lipid metabolism, adipokine secretion, and insulin sensitivity (Rangwala and Lazar 2004). PPAR $\gamma$ binds near most adipogenic genes as a heterodimer with retinoid $\mathrm{X}$ receptor (RXR) (Lefterova et al. 2008; Nielsen et al. 2008).

$\operatorname{PPAR} \gamma$, like most NRs, is a ligand-dependent transcription factor (TF) (Glass and Rosenfeld 2000). High-affinity ligands for PPAR $\gamma$ include the thiazolidinediones (TZDs) (Lehmann et al. 1995), which are insulin-sensitizing drugs (Nolan et al. 1994). TZDs contribute to insulin sensitization by acting on adipose tissue to regulate gene transcription

\footnotetext{
${ }^{8}$ These authors contributed equally to this work.

${ }^{9}$ Corresponding author

E-mail lazar@mail.med.upenn.edu

Article is online at http://www.genesdev.org/cgi/doi/10.1101/gad.237628.114.
}

both positively and negatively. For example, TZDs induce insulin-sensitizing factors adiponectin (Maeda et al. 2001) and FGF-21 (Moyers et al. 2007) while suppressing the expression of genes promoting insulin resistance, including TNF $\alpha$ (Hofmann et al. 1994), resistin (Steppan et al. 2001), and retinol-binding protein 4 (Yang et al. 2005). The most potent TZD in the clinic is rosiglitazone (rosi) (Lehmann et al. 1995), which has durable anti-diabetic effects but, unfortunately, has toxicities that limit its widespread use (Kung and Henry 2012; Ahmadian et al. 2013). Because PPAR $y$ expression in adipose tissue is required for the in vivo systemic insulin-sensitizing effects of TZDs (Chao et al. 2000; He et al. 2003), it is critical to understand how rosi binding to PPAR $\gamma$ modulates gene expression.

Binding of rosi to PPAR $\gamma$ results in recruitment of coactivators, including SRC-1, CBP, p300, and MED1,

(C) 2014 Step et al. This article is distributed exclusively by Cold Spring Harbor Laboratory Press for the first six months after the full-issue publication date (see http://genesdev.cshlp.org/site/misc/terms.xhtml). After six months, it is available under a Creative Commons License (AttributionNonCommercial 4.0 International), as described at http://creativecommons. org/licenses/by-nc/4.0/. 
that function to induce gene expression (Westin et al. 1998; Gelman et al. 1999; Ge et al. 2002; Bugge et al. 2009). However, the mechanism by which rosi represses transcription is not well understood. In macrophages, studies implicate rosi-dependent SUMOylation of PPAR $\gamma$, which tethers to the NR corepressor (NCoR) to prevent the induction of inflammatory genes by endotoxin (Pascual et al. 2005). However, this mechanism pertains only to prevention of induction by toll-like receptor stimulation and has not been demonstrated in other cell types (Huang and Glass 2010). Another proposed mechanism involves the ligand-dependent recruitment of corepressors, in which rosi treatment results in the recruitment of corepressors CTBP1 and CTBP2 to C/EBP $\alpha$ by an unknown mechanism (Vernochet et al. 2009).

Ligand binding to other NRs has been suggested to repress gene expression by recruiting limiting coactivators away from other TFs, thereby repressing those target genes. Support for this coactivator competition model, often referred to as squelching, has been largely based on TF overexpression experiments in transfection systems /Gill and Ptashne 1988; Kelleher et al. 1990; Kamei et al. 1996; Fronsdal et al. 1998; Lee et al. 2000; Li et al. 2000; Kim et al. 2001; Zhang and Teng 2001; Manna and Stocco 2007; He et al. 2012; Pascual-Garcia et al. 2013), although a recent study demonstrated coactivator redistribution with endogenous factors and chromatin on a genome-wide scale in the context of E2-treated MCF-7 cells (He et al. 2012).

Many studies have used transcriptome analysis to infer the effects of rosi on steady-state gene expression in adipocytes (Li and Lazar 2002; Sears et al. 2007; Choi et al. 2010; Rong et al. 2011). However, steady-state mRNA levels are determined by their rates of both transcription and degradation. Here, for the first time, we directly measured rates of adipocyte transcription genome-wide using global run-on followed by sequencing (GRO-seq) (Core et al. 2008). We found that rosi rapidly up-regulates or down-regulates the transcription of thousands of adipocyte genes, and this regulation correlates highly with steady-state mRNA regulation. We also identified thousands of bidirectional, intergenic transcripts that fit the criteria of enhancer RNAs (eRNAs) (De Santa et al. 2010; Kim et al. 2010), which have been shown to mark functional enhancers and regulate the transcription of the nearest gene (Kaikkonen et al. 2013; Lam et al. 2013; Li et al. 2013; Melo et al. 2013), and demonstrate that rosi regulates eRNA transcription in a manner that is related to activation of the nearby gene bodies.

Rosi-up-regulated eRNAs occurred at sites of strong PPAR $\gamma$ binding to which coactivators such as MED1, CBP, and p300 were recruited. Remarkably, however, downregulation of eRNA transcription occurred at sites that are devoid of PPAR $\gamma$ but enriched for C/EBP and AP-1 family members. MED1 and other coactivators were dismissed at these down-regulated sites, strongly supporting a mechanism of negative regulation involving coactivator redistribution upon rosi binding to PPAR $\gamma$. Thus, analysis of regulated eRNAs reveals a novel mechanism by which rosi represses adipocyte gene transcription at endogenous levels of PPAR $\gamma$ and other TFs on a genome-wide scale.

\section{Results}

Rosi rapidly and robustly regulates gene transcription in adipocytes

GRO-seq (Core et al. 2008; Wang et al. 2011) was used to measure nascent gene transcription in mouse 3T3-L1 adipocytes and after treatment with rosi for $10 \mathrm{~min}$, $30 \mathrm{~min}, 1 \mathrm{~h}$, and $3 \mathrm{~h}$. The Fabp4 locus, a classic adipocyte PPAR $\gamma$ gene target (Spiegelman and Green 1980; Rival et al. 2004), showed increased transcription with rosi treatment (Fig. 1A). In contrast, transcription from the Rgs2 gene body was rapidly repressed by rosi (Fig. 1B), consistent with the behavior of the mRNA (Sears et al. 2007). Overall, 1951 annotated RefSeq genes were transcriptionally regulated by rosi at one or more of the time points tested (Fig. 1C). Interestingly, $71 \%$ of regulated nascent transcripts were repressed, whereas only $29 \%$ were activated by rosi.

\section{Regulation of nascent gene transcription by rosi correlates with changes in $m R N A$ levels}

To assess the temporal and gene-specific relationship between nascent gene transcription and steady-state mRNA levels, we determined the adipocyte transcriptome using gene expression microarrays after $30 \mathrm{~min}, 1 \mathrm{~h}, 2 \mathrm{~h}, 6 \mathrm{~h}$, $12 \mathrm{~h}, 24 \mathrm{~h}, 36 \mathrm{~h}$, and $48 \mathrm{~h}$ of rosi treatment, with three biological replicates at each time point (Fig. 2). While the nascent transcription of many genes was regulated as early as 10 and $30 \mathrm{~min}$ after rosi, very few mRNA transcripts changed during this time period and for at least $2 \mathrm{~h}$ after rosi treatment. This was not surprising, as the time required to reach new steady-state levels is related to the rate of degradation rather than the rate of synthesis (Schimke and Doyle 1970). However, the correlation between nascent transcription and steady-state mRNA levels was high at later time points, with the greatest correlation noted between the transcription regulation at $3 \mathrm{~h}$ and the mRNA regulation measured $6 \mathrm{~h}$ after rosi. The lower correlation with later microarray time points suggests that steady-state regulation at these later times may be dependent on secondary transcriptional changes occurring later than $3 \mathrm{~h}$ of treatment. Importantly, direct transcriptional regulation by rosi in this model was highly similar to recently published regulation of in vivo adipose tissue gene expression in rosi-treated mice, suggesting that many of the rosi-dependent changes that we describe are physiologically relevant (Supplemental Fig. S1; Ohno et al. 2012).

\section{Rosi regulates transcription of eRNAs that correlate with gene transcription}

In addition to gene body transcription, GRO-seq revealed robust bidirectional transcripts at enhancers or eRNAs (Core et al. 2008; Kim et al. 2010), which were identified and quantified in an unbiased, genome-wide analysis (Fig. 3A). For example, bidirectional eRNAs were identified at enhancers upstream of the Fabp4 locus, and their transcription was observed to be up-regulated by rosi (Fig. 3B). Indeed, unbiased de novo calling of bidirectional inter- 


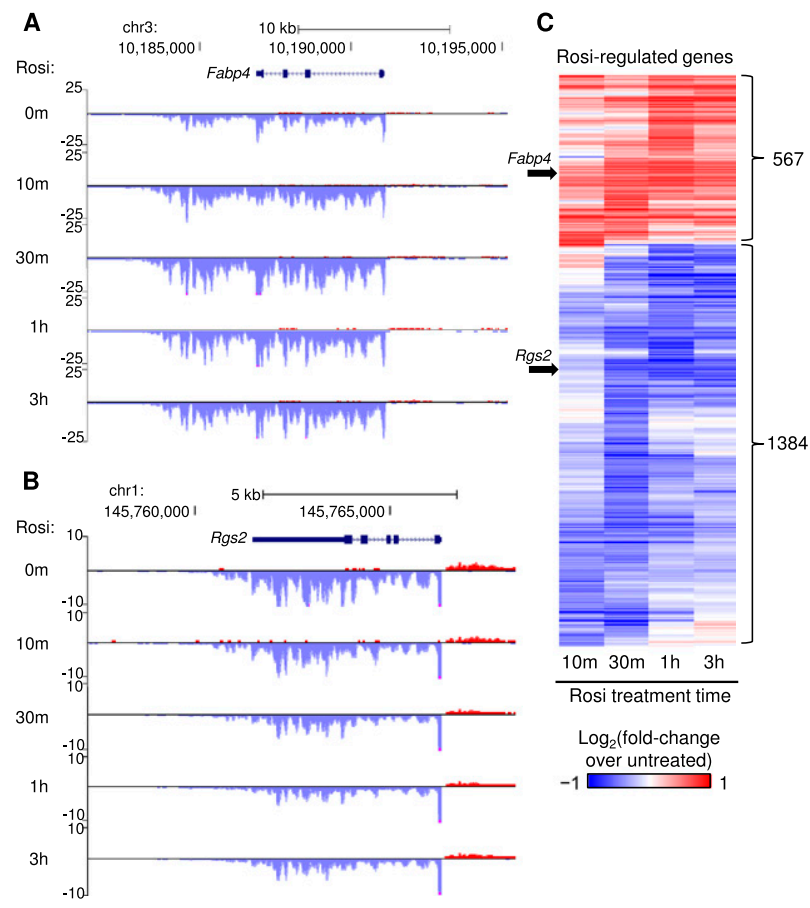

Figure 1. Rosi rapidly increases and represses gene transcription in adipocytes. GRO-seq was performed on mature 3T3-L1 adipocytes treated for $0,10 \mathrm{~min}, 30 \mathrm{~min}, 1 \mathrm{~h}$, or $3 \mathrm{~h}$ with rosi. $(A)$ Increased transcription at the Fabp4 locus with rosi treatment. (B) The Rgs2 gene shows repressed transcription upon rosi treatment. $(C)$ The heat map shows 1951 genes that displayed a significant change in transcription (false discovery rate [FDR] $<0.05$ ) due to rosi treatment in at least one time point.

genic transcripts confirmed that the transcription of many eRNAs was strongly and rapidly regulated by rosi, and down-regulated eRNAs greatly outnumbered up-regulated eRNAs (Fig. 3C). This was similar to the effect of rosi on gene body transcription, and, as has been observed in other systems (De Santa et al. 2010; Kim et al. 2010), the effect of rosi on eRNA transcription correlated strongly with transcription at the nearby gene bodies (Fig. 3D; Supplemental Fig. S2A). The correlation was confirmed at eRNA/gene body pairs by quantitative PCR (qPCR), which also demonstrated that eRNA induction often preceded gene induction (Fig. 3E; Supplemental Fig. S2B). The correlation was validated at repressed eRNA/gene pairs as well (Supplemental Fig. S2C). Although intragenic eRNAs were excluded from downstream analysis because of difficulties in identifying them reliably, we observed that many follow a similar pattern of correlation with the target gene (Supplemental Fig. S3).

\section{PPAR $\gamma$ directly mediates the induction of eRNA and gene transcription by rosi}

De novo motif-finding analysis at sites of rosi-induced eRNAs revealed strong enrichment for a sequence that is highly similar to the canonical PPAR $\gamma /$ RXR-binding site (Fig. 4A; Supplemental Fig. S4). Indeed, up-regulated eRNAs were extremely likely to have PPAR $\gamma$ bound nearby $(85 \%)$, much more so than unregulated or down-regulated eRNAs
(Fig. 4B). In fact, down-regulated eRNAs were relatively devoid of PPAR $\gamma$ binding, as discussed below. Furthermore, strong PPAR $\gamma$ binding as measured by total normalized tag counts from chromatin immunoprecipitation (ChIP) coupled with deep sequencing (ChIP-seq) was enriched at upregulated eRNAs, but not at down-regulated eRNAs, relative to unregulated eRNAs (Fig. 4C). PPAR $\gamma$-binding sites that overlap with eRNAs had higher PPAR $\gamma$ occupancy than those that lack eRNAs, further suggesting that enhancers with eRNAs are more likely to be functional (Supplemental Fig. S5). Moreover, knockdown of PPAR $\gamma$ abrogated basal eRNA transcription at rosi-up-regulated sites (Fig. 4D; Supplemental Fig. S6), indicating that PPAR $\gamma$ binding was required for eRNA transcription at these sites.

In addition to regulating eRNAs, PPAR $\gamma$ binding was critical for the regulation of gene body transcription as well. Up-regulated genes were statistically significantly enriched for PPAR $\gamma$ sites closer to the transcription start site (TSS) compared with down-regulated or unregulated genes (Fig. 4E). Furthermore, up-regulated genes had significantly more PPAR $\gamma$-binding sites within $100 \mathrm{~kb}$ of the TSS (Fig. 4F). Together, these data strongly support the

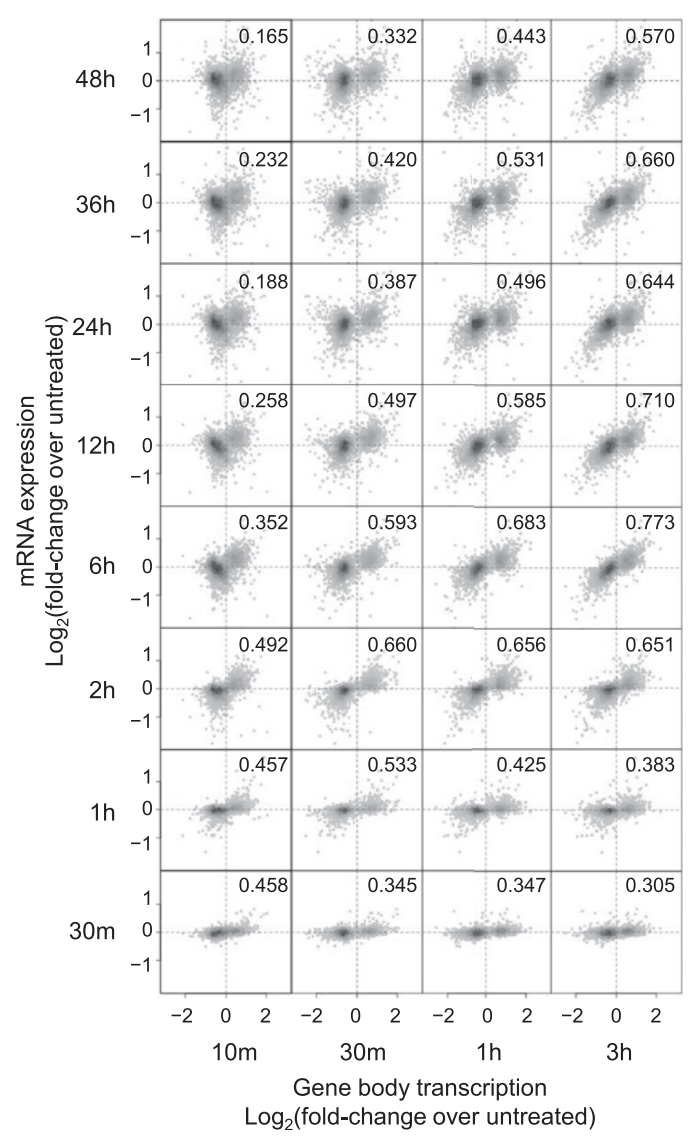

Figure 2. Adipocyte gene body transcription levels correlate with steady-state mRNA levels. Correlation between microarray mRNA levels and GRO-seq transcription levels is plotted at each time point. The Pearson correlation coefficient is given for each pair of time points. 
A
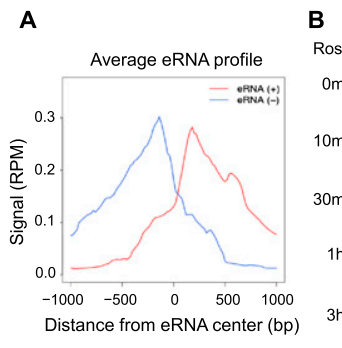

C

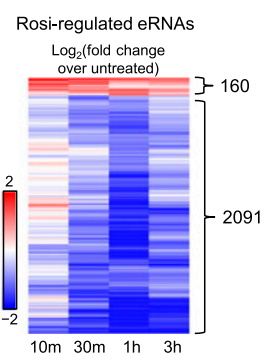

E

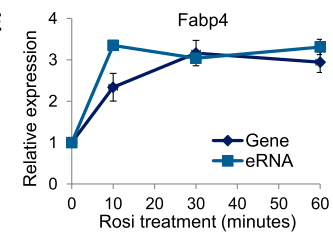

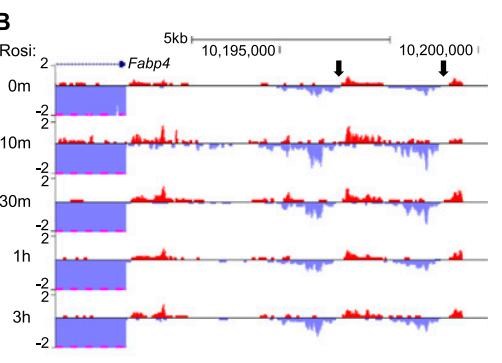

D
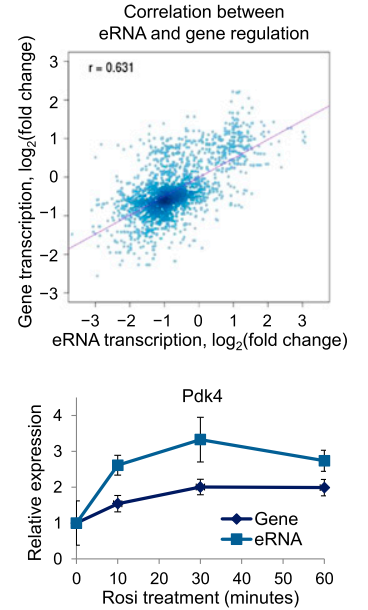

Figure 3. Adipocyte eRNA transcription is stimulated by rosi and correlates with gene body transcription. (A) Genome-wide average signal of intergenic bidirectional transcripts in untreated adipocytes from the plus and minus strands. $(B)$ Two bidirectional eRNAs are transcribed at enhancers upstream of the Fabp4 TSS and up-regulated by rosi treatment. eRNA centers are indicated by arrows. $(C)$ Heat map showing all rosi-regulated eRNAs found in an unbiased manner $(N=2251)$. (D) Correlation between rosiregulated eRNAs and the regulation of the nearby gene for all pairs of matching time points $(N=462)$. For each gene, eRNAs within $100 \mathrm{~kb}$ of the TSS were included in the analysis. $(E)$ Correlation between gene and eRNA rosi regulation as measured by RT-qPCR for two example genes, Fabp 4 and Pdk4. $N=3$. Error bars indicate SEM.

model that rosi up-regulates gene expression by binding to PPAR $\gamma$ at enhancer sites proximal to the TSS, where it directly stimulates eRNA as well as gene body transcription.

\section{Repression of eRNA transcription by rosi is not directly mediated by PPAR $\gamma$}

In contrast to the up-regulation of transcription by rosi, the PPAR $\gamma$ motif and strength of binding were not enriched at rosi-repressed eRNAs. Although 23.6\% of down-regulated eRNAs had PPAR $\gamma$ bound (Fig. 4B), this percent was far less than at unregulated eRNAs, and the binding tended to be extremely weak (Fig. 4C). In addition, in contrast to its effect on up-regulated eRNAs, knockdown of PPAR $\gamma$ did not affect basal expression of rosi-down-regulated eRNAs (Fig. 4D). Moreover, unlike up-regulated genes, the number, strength, and proximity of PPAR $\gamma$ binding were not enriched near the TSS of

down-regulated genes relative to unchanged genes (Fig. $4 \mathrm{E}, \mathrm{F})$. Together, these data strongly suggest that PPAR $\gamma$ does not mediate the repression of eRNA and gene body transcription by rosi directly; i.e., by binding in cis with the regulated gene body, as was the case at the majority of rosi-up-regulated eRNAs.

De novo motif analysis of sites with down-regulated eRNAs produced two highly enriched motifs that most resembled a C/EBP:AP-1 hybrid motif and the canonical AP-1 motif (Fig. 5A; Supplemental Fig. S7). ChIP-seq analysis for C/EBP and AP-1 factors that are abundant in adipocytes revealed significant enrichment at down-regulated eRNAs of both C/EBP $\alpha$ and FOSL2 (Fig. 5B), which has been shown to play a role in adipocyte gene expression (Wrann et al. 2012). A higher percentage of downregulated eRNAs, compared with up-regulated and nonregulated, had $\mathrm{C} / \mathrm{EBP} \alpha$ and FOSL2 bound, and, interestingly, although $\mathrm{C} / \mathrm{EBP} \alpha$ has been shown to be enriched near genes repressed after rosi treatment (Vernochet et al. 2009; Haakonsson et al. 2013), the enrichment was

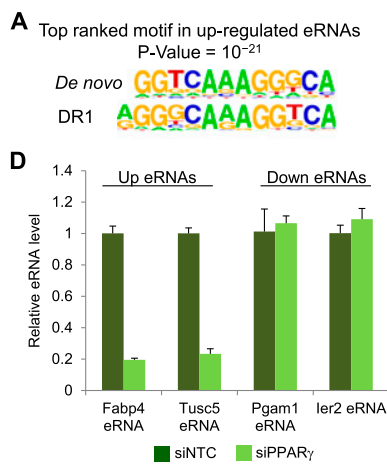

E

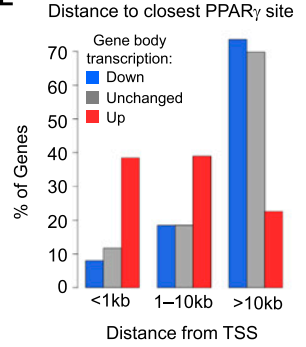

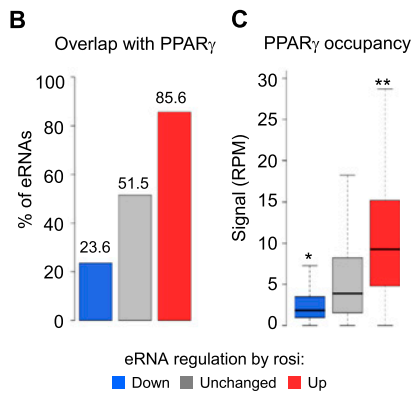

$\mathbf{F}$

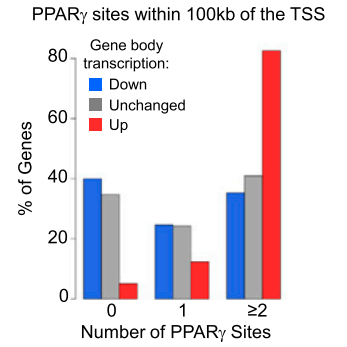

Figure 4. Rosi-up-regulated eRNAs are dependent on genomic binding of PPAR $\gamma$. $(A)$ Top hit from Homer de novo motif search at up-regulated eRNAs. The closest known motif, the DR1 motif, is shown for reference. The enrichment for this motif was $45 \%$ in the target sites and $13.5 \%$ in the background sites. (B) Percentage of upregulated, down-regulated, and unregulated eRNA sites that overlap with a called PPAR $\gamma$ peak from ChIP-seq. There were 14,604 called $\operatorname{PPAR} \gamma$ peaks in our data set. Among those, 5819 sites were extragenic, and 3642 sites had eRNAs. $(C)$ Total PPAR $\gamma$ tag count in reads per million (RPM) within $1 \mathrm{~kb}$ of up-regulated, downregulated, and unregulated eRNA sites. $\left(^{\star}\right) P=7.7 \times 10^{-95}$ versus unregulated; $\left(^{\star \star}\right) P=1.8 \times 10^{-20}$ versus unregulated. $(D)$ RT-qPCR of eRNAs $24 \mathrm{~h}$ after siRNA knockdown of PPAR $\gamma . N=3$. Error bars indicate SEM. (E) Distance from TSS to the closest PPAR $\gamma$ sites for regulated genes. $P<10^{-10}$ for up-regulated versus unregulated sites by $\chi^{2}$ test. $(F)$ Number of PPAR $\gamma$-binding sites within $100 \mathrm{~kb}$ of the TSS for regulated genes. $P<10^{-10}$ for up-regulated versus unregulated sites by $\chi^{2}$ test. 
A

\begin{tabular}{|c|c|c|}
\hline \multicolumn{3}{|c|}{ Top ranked motifs in down-regulated eRNAs } \\
\hline & P-Value $=10^{-172}$ & P-Value $=10^{-116}$ \\
\hline De novo & TATTCCATCAT'A & De novo 후댓슨 \\
\hline EBP:AP-1 & 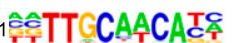 & 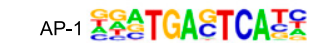 \\
\hline
\end{tabular}

B

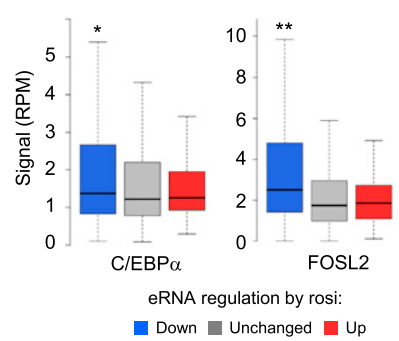

C

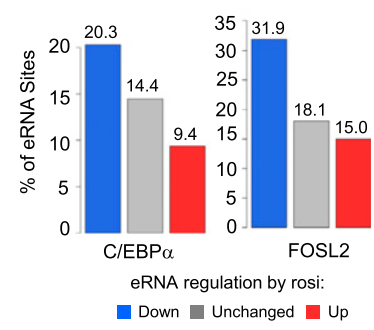

Figure 5. Enrichment of C/EBP and AP-1 factors at downregulated eRNAs. (A) Top two hits from Homer de novo motif search at down-regulated eRNAs. The closest known motif for each is shown for reference. $(B)$ Total C/EBP $\alpha$ and FOSL2 tag counts in reads per million (RPM) within $1 \mathrm{~kb}$ of the center of regulated eRNAs from ChIP-seq. $\left(^{*}\right) P=4.6 \times 10^{-8}$ versus unregulated; $\left(^{\star \star}\right) P=8.9 \times 10^{-46}$ versus unregulated. $(C)$ Percentage of regulated eRNAs that overlap with called C/EBP $\alpha$ or FOSL2 peaks.

higher for FOSL2 (Fig. 5C). Other factors tested, including C/EBP $\beta$, ATF2, and JUND, also showed enrichment at down-regulated eRNAs (Supplemental Fig. S8), and the strength of this binding did not change upon rosi treatment (Supplemental Fig. S9). The finding that both $\mathrm{C} / \mathrm{EBP}$ factors and all three AP-1 factors are enriched at down-regulated sites suggests that each of these factors, potentially along with other TFs but notably not PPAR $\gamma$, is located at eRNAs in cis with gene bodies whose transcription is negatively regulated by rosi.

\section{Rosi redistributes coactivator MED1 binding from down-regulated eRNAs to up-regulated eRNAs}

The majority of eRNA up-regulation occurred by $10 \mathrm{~min}$ after addition of rosi, whereas the number of down-regulated eRNAs was markedly fewer at that time and peaked at $1 \mathrm{~h}$ (Fig. 6A). Given the direct nature of rosi regulation of the up-regulated eRNAs via PPAR $\gamma$, we hypothesized that the delayed down-regulation could be related to coactivator redistribution to the rosi-bound PPAR $\gamma$. ChIP-seq for the general coactivator MED1 was performed in the presence and absence of rosi. We then determined the sites of MED1 occupancy that contained eRNAs and whether these eRNAs were up-regulated or down-regulated by rosi (Fig. 6B). As expected, MED1 recruitment to sites of PPAR $\gamma$ binding at up-regulated eRNAs was increased by rosi (Fig. 6C).

Remarkably, $1 \mathrm{~h}$ of rosi treatment decreased MED1 recruitment at sites of down-regulated eRNA transcription despite the general absence of PPAR $\gamma$ at these sites (Fig. 6D). These results were confirmed at several representative sites of up-regulated and down-regulated eRNAs by MED1 ChIP-qPCR (Fig. 6E) as well as by an independent

ChIP-seq replicate (Supplemental Fig. S10). On average, upon rosi treatment, MED1 recruitment significantly decreased at down-regulated eRNAs and increased at upregulated eRNAs relative to unregulated eRNAs (Fig. 6F). Moreover, when restricted to eRNAs with MED1 binding only, C/EBP and AP-1 factor binding at down-regulated eRNA sites displayed more significant enrichment as compared with unregulated eRNA sites (Supplemental Fig. S11). Since PPAR $\gamma$ was markedly enriched at sites of up-regulated eRNAs, these data together suggest that rosi binding to PPAR $\gamma$ redistributed MED1 binding from the sites of down-regulated eRNAs to the sites of up-regulated eRNAs. Thus, binding of rosi to PPAR $\gamma$ directly activated eRNA transcription at up-regulated sites, and the resultant redistribution of coactivator led to downregulation of eRNA transcription mediated by other TFs at sites not bound by PPAR $\gamma$.

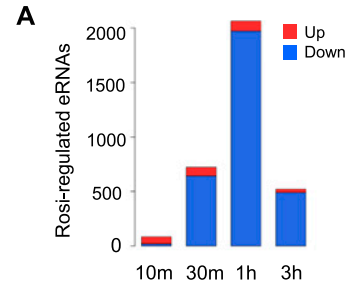

C

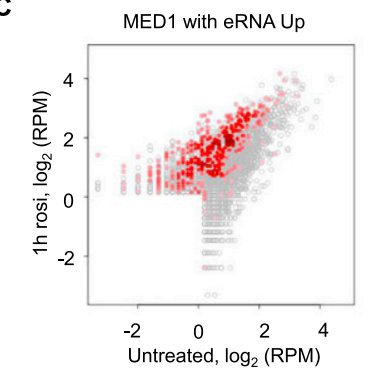

E

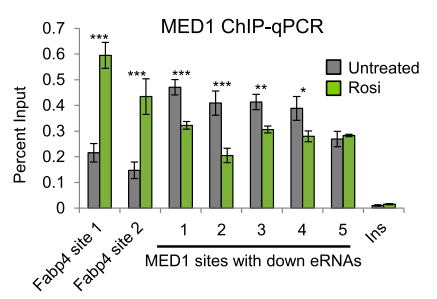

B

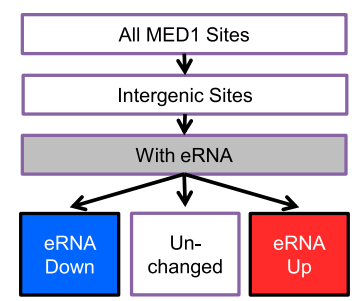

D

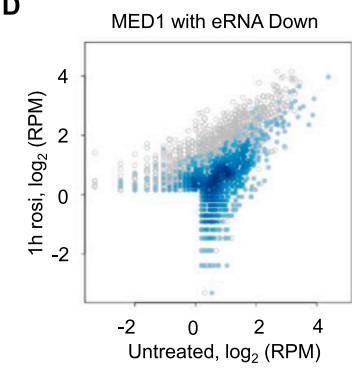

$\mathbf{F}$

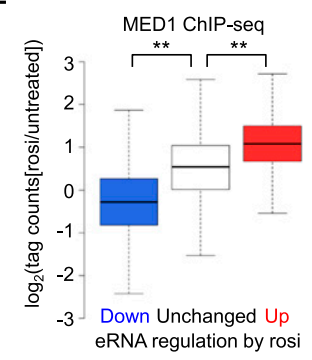

Figure 6. Redistribution of MED1 genomic occupancy upon rosi treatment. (A) Number of eRNAs up-regulated or downregulated at each time point. $(B)$ Work flow for identification of MED1-binding sites with regulated eRNAs. (C) Scatter plot comparing MED1-binding strength in reads per million (RPM) with and without $1 \mathrm{~h}$ of rosi treatment, with sites containing an up-regulated eRNA highlighted in red. (D) Scatter plot comparing MED1-binding strength with and without $1 \mathrm{~h}$ of rosi treatment, with sites containing a down-regulated eRNA highlighted in blue. (E) MED1 ChIP-qPCR at sites with up-regulated or down-regulated eRNAs. $N=5$. Error bars indicate SEM. $\left({ }^{\star}\right) P<$ $\left.0.05 ;\left(^{\star \star}\right) P<0.01{ }^{* \star \star}\right) P<0.005$ by paired $t$-test. $(F)$ Box plot showing average change in MED1 genome-wide occupancy upon rosi treatment at sites of regulated eRNAs. $\left(^{\star \star}\right) P<10^{-15}$. 
In support of this, at the minority of down-regulated eRNAs where PPAR $\gamma$ binding was observed, the strength of PPAR $y$ binding was markedly reduced relative to upregulated sites (Supplemental Fig. S12A). Furthermore, in stark contrast to the PPAR $\gamma$-associated up-regulated eRNAs (but consistent with the non-PPAR $\gamma$-associated down-regulated eRNAs), knockdown of PPAR $\gamma$ did not significantly alter basal eRNA transcription at these down-regulated eRNAs (Supplemental Fig. S12B), indicating that the weakly bound PPAR $\gamma$ was not functional. Consistent with this, rosi treatment led to loss of MED1 at these sites (Supplemental Fig. S12C), just as was noted at down-regulated eRNAs devoid of PPAR $\gamma$ binding. The basal magnitude of binding of MED1 at unchanged eRNAs was not significantly different from at downregulated eRNAs (Supplemental Fig. 13). The reason for this is not clear, but presumably, additional factors, potentially including histone marks or cooperating TFs, may be involved in determining which eRNAs will be down-regulated by rosi treatment.

Furthermore, redistribution of a coactivator to up-regulated sites and away from repressed sites was not limited to only MED1. ChIP-seq for the coactivators CREB-binding protein $(\mathrm{CBP})$ and p300 in the presence and absence of rosi showed a modest but consistent and statistically significant redistribution upon rosi treatment similar to MED1 (Supplemental Fig. S14). These data support the model that upon rosi treatment, coactivators are redistributed to strong, functional PPAR $\gamma$ sites and away from enhancers containing weakly bound PPAR $\gamma$ and other TFs. Surprisingly, we did not observe significant changes in H3K27ac at sites of eRNAs regulated after $1 \mathrm{~h}$ of rosi treatment, although we cannot rule out changes in chromatin marks at later time points (Supplemental Fig. S15). Also, in contrast to the three coactivators tested, rosi treatment did not cause global redistribution of NCoR (Supplemental Fig. S16).

\section{Discussion}

The present analysis of how rosi influences genome-wide transcription rates in adipocytes has revealed much about the mechanisms of action of this anti-diabetic PPAR $\gamma$ ligand. These studies provide a higher-resolution and more dynamic portrait of rosi-regulated gene transcription than previously possible. Earlier reports of rosiregulated gene expression using microarray or RNA polymerase II ChIP-seq found a few hundred regulated genes, with half or slightly more than half of those being upregulated by rosi (Choi et al. 2010; Haakonsson et al. 2013). In contrast, we found that transcription is regulated at almost 2000 gene bodies, more than two-thirds of which are repressed in response to ligand treatment. We believe that this increased sensitivity arises from the GRO-seq technique as well as from the use of multiple time points to capture various dynamics of direct transcriptional regulation.

Rosi regulates nascent gene transcription within $10 \mathrm{~min}$ of treatment, and this correlates well with steady-state mRNA regulation. The correlation is delayed, as expected, since changes in gene body transcription precede those of the mRNAs and because the time to reach a new steadystate mRNA level is independent of the rate of synthesis and dependent solely on the mRNA half-life (Schimke and Doyle 1970). The correlation between early transcription rates and steady-state mRNA levels waned at later time points, presumably due to secondary effects of rosi, such as induction of other TFs or mRNA-degrading systems.

eRNAs are of great interest, as they have been shown to contribute to enhancer function and influence transcription at the target gene body (Kaikkonen et al. 2013; Lam et al. 2013; Li et al. 2013; Melo et al. 2013). We were able to detect adipocyte eRNAs, and quantification of their basal and rosi-regulated rates of transcription revealed a high correlation between eRNA transcription and transcription at the nearby genes. At rosi-up-regulated eRNAs, PPAR $\gamma$ binding was highly enriched and was actually required for eRNA transcription. Up-regulation of transcription by rosi was correlated with recruitment of the coactivators MED1, CBP, and p300 to the site of eRNA transcription, in agreement with a recent study that found that MED1 was recruited to PPAR $\gamma$-binding sites (Haakonsson et al. 2013). Up-regulation of gene transcription by rosi was also favored by the number, strength, and proximity of PPAR $\gamma$-binding sites relative to the TSS. Thus, activation of gene transcription by rosi fits a general model of NR function in which ligand binding facilitates the recruitment of coactivators to PPAR $\gamma$ bound in cis with a regulated gene body. The site of PPAR $\gamma$ binding functions as an enhancer, generating eRNAs that correlate with the level of gene body transcription. The effect is greatest when multiple strong PPAR $\gamma$-binding events occur in relatively close proximity to the TSS.

In contrast, rosi-down-regulated eRNAs are quite different. They are depleted of PPAR $y$ binding compared with background levels but are enriched for other TFs, especially members of the C/EBP and AP-1 TF families. These eRNAs were not dependent on PPAR $\gamma$ expression, further indicating the absence of a direct role of PPAR $\gamma$ in their transcription. Nevertheless, despite the fact that PPAR $\gamma$ is not bound in the vicinity, rosi treatment leads to dismissal of the coactivators from these sites. This suggests that a primary mechanism of rosi-dependent transcriptional repression involves squelching of essential coactivators from enhancers lacking PPAR $\gamma$. Consistent with this, the induction of the PPAR $\gamma$-dependent, rosiinduced eRNAs preceded the down-regulation of nonPPAR $\gamma$-dependent eRNAs.

In contrast to up-regulated enhancers, which depend on activation of PPAR $\gamma$ and recruitment of coactivators such as MED1, down-regulated sites where MED1 binding was lost were enriched for TFs other than PPAR $\gamma$. This suggests that, in principle, any TF driving transcription at a PPAR $\gamma$-independent enhancer would be susceptible to the repressive effects of rosi redistributing coactivators to PPAR $\gamma$. Indeed, this may explain why the downregulated enhancers are enriched for binding of multiple factors, including $\mathrm{C} / \mathrm{EBP} \alpha, \mathrm{C} / \mathrm{EBP} \beta, \mathrm{FOSL} 2, \mathrm{ATF} 2$, and 
JUND. Of these, only $\mathrm{C} / \mathrm{EBP} \alpha$ has previously been implicated in rosi-mediated transcriptional repression (Vernochet et al. 2009; Haakonsson et al. 2013), and notably, in our studies, $\mathrm{C} / \mathrm{EBP} \alpha$ was less enriched at down-regulated sites relative to the AP-1 TFs.

A role for coactivator redistribution or squelching has been previously suggested to explain transcriptional repression by NRs, but most of those studies were performed using transfection to overexpress receptors or coactivators and used reporter genes as readouts (Kamei et al. 1996; Fronsdal et al. 1998; Lee et al. 2000; Li et al. 2000; Kim et al. 2001; Zhang and Teng 2001; Manna and Stocco 2007; He et al. 2012; Pascual-Garcia et al. 2013). This model gained further support recently with evidence that the endogenous coactivator NCOA3 is lost from sites of diminished DNase I hypersensitivity upon E2 hormone treatment in MCF-7 cells (He et al. 2012). Here our analysis of eRNAs has allowed us to focus on regulated enhancers and interrogate this mechanism in the context of the endogenous genome and TFs in adipocytes, where the only manipulation was treatment with the PPAR $y$ ligand, and link the coactivator redistribution to changes in transcriptional levels of both eRNAs and genes.

In macrophages, the transrepression model has become the primary mechanism to explain PPAR $\gamma$-mediated gene repression (Glass and Saijo 2010). In this model, rosi treatment causes the SUMOylation and subsequent tethering of bound PPAR $\gamma$ to promoters of inflammatory genes already bound by NF- $\kappa \mathrm{B}$ and other factors, blocking the dismissal of the corepressor complex from those sites (Pascual et al. 2005). However, this has only been demonstrated at select promoters of inflammatory genes and pertains only to the role of rosi in blocking the activating effect of endotoxin. Hence, it likely does not explain the majority of genome-wide transcriptional repression. It should be noted that the transrepression model requires PPAR $\gamma$ binding, albeit by a tethering model, whereas we observed that the majority of rosidown-regulated eRNAs in adipocytes are actually depleted of PPAR $\gamma$.

Thus, our study of nascent gene transcription in adipocytes has not only revealed a rapid transcriptional response to rosi that precedes yet is highly correlated with steadystate mRNA levels but has also demonstrated that rosi regulates adipocyte eRNAs in a manner that is highly correlated with gene body transcription. Bioinformatic, genomic, and genetic analysis of these eRNAs has provided strong evidence that rosi-dependent activation and repression of transcription are mediated by two fundamentally different mechanisms, with activation occurring at sites of PPAR $\gamma$ binding and repression occurring at sites that are basally activated by other TFs and whose coactivator recruitment is destabilized when rosi binds to $\operatorname{PPAR} \gamma$ and increases its affinity for coactivators. Adipocytes express PPAR $\gamma$ at very high levels, which likely contributes to both the strength of PPAR $\gamma$ binding at rosiup-regulated eRNAs and the redistribution of coactivators away from other TFs in the setting of ligand activation of PPAR $\gamma$.

\section{Materials and methods}

\section{Cell culture}

3T3-L1 cells were obtained from American Type Culture Collection and grown in DMEM (Invitrogen) supplemented with $10 \%$ fetal bovine serum (Tissue Culture Biologics), $100 \mathrm{U} / \mathrm{mL}$ penicillin, and $100 \mu \mathrm{g} / \mathrm{mL}$ streptomycin (Invitrogen). Two days post-confluence, differentiation medium (growth medium with $1 \mu \mathrm{M}$ dexamethasone, $10 \mu \mathrm{g} / \mathrm{mL}$ human insulin, and $0.5 \mathrm{mM}$ 3-isobutyl-1-methylxanthine [Invitrogen]) was added. Cells were differentiated as described previously (Lefterova et al. 2008) by growth in differentiation medium for $2 \mathrm{~d}$, followed by growth medium with insulin for $2 \mathrm{~d}$, followed by growth medium only. When indicated, mature 3T3-L1 adipocytes were treated with $1 \mu \mathrm{M}$ rosi (Biomol) dissolved in DMSO.

\section{Gene expression analysis}

RNA was isolated from cells using TRIzol (Invitrogen) followed by the RNeasy minikit (Qiagen). RT-PCR was performed using $1 \mu \mathrm{g}$ of RNA (Applied Biosystems) following the manufacturer's instructions, and qPCR was performed using primers listed in Supplemental Table S1 using Power SYBR Green master mix (Applied Biosystems) on the PRISM 7500 and 7900HT instruments (Applied Biosystems). Analysis was performed using the standard curve method, and all genes were normalized to the housekeeping gene Arbp. For the microarray, RNA integrity was examined using an Agilent 2100 Bioanalyzer. RNA samples (150 ng) with RNA integrity number $>7$ were used for target amplification and labeling via the Ambion WT Expression kit (no. 4411974) and Affymetrix WT Terminal-Labeling kit (no. 900671) following the manufacturer's protocol. Mouse Gene 1.1 ST array plates (no. 901418, Affymetrix) were used for microarray hybridization, wash, stain, and scan with GeneTitan hyb-wash-stain kits (no. 901622, Affymetrix) and a GeneTitan instrument. GeneTitan scanner data were collected with default parameters and further analyzed using the Partek genomics suite. Data were normalized using the default Robust Multichip Average (RMA) method. For each gene, an average was taken across replicates for the comparative analysis with GRO-seq gene transcriptional level.

\section{GRO-seq library preparation}

GRO-seq was performed as previously described (Core et al. 2008; Wang et al. 2011). Cells were washed twice with ice-cold PBS and then swelled in cold swelling buffer $(10 \mathrm{mM}$ Tris at $\mathrm{pH}$ $7.5,2 \mathrm{mM} \mathrm{MgCl}_{2}, 3 \mathrm{mM} \mathrm{CaCl}_{2}$ ) for $5 \mathrm{~min}$ on ice. Cells were scraped off and centrifuged at $400 \mathrm{~g}$ for $10 \mathrm{~min}$, resuspended in 10 $\mathrm{mL}$ of lysis buffer (swelling buffer with $10 \%$ glycerol, $1 \%$ Igepal), and incubated for $5 \mathrm{~min}$ on ice. Nuclei were washed twice with lysis buffer and then resuspended in freezing buffer $(50 \mathrm{mM}$ Tris at $\mathrm{pH} 8.3,40 \%$ glycerol, $5 \mathrm{mM} \mathrm{MgCl}_{2}, 0.1 \mathrm{mM}$ EDTA). Nuclei were counted and pelleted, and $5 \times 10^{6}$ nuclei were resuspended in $100 \mu \mathrm{L}$ of freezing buffer. For each library, run-on was performed on four tubes of $5 \times 10^{6}$ nuclei.

For the run-on, cells were mixed with an equal volume of runon buffer (10 mM Tris at pH 8.0; $5 \mathrm{mM} \mathrm{MgCl}_{2} ; 1 \mathrm{mM}$ DTT; 300 $\mathrm{mM} \mathrm{KCl} ; 20 \mathrm{U}$ of SUPERase-In; $1 \%$ Sarkosyl; $500 \mu \mathrm{M}$ ATP, GTP, and $\mathrm{Br}-\mathrm{UTP} ; 2 \mu \mathrm{M} \mathrm{CTP} /$ preheated to $30^{\circ} \mathrm{C}$ and incubated for $5 \mathrm{~min}$ at $30^{\circ} \mathrm{C}$. Nuclear RNA was extracted with TRIzol (Invitrogen) and chloroform and precipitated with $\mathrm{NaCl}$ and ethanol overnight. The RNA pellet was resuspended in water, and the RNA was DNase-treated (Ambion) for $30 \mathrm{~min}$. RNA was hydrolyzed using fragmentation reagents (Ambion) for $13 \mathrm{~min}$ at $70^{\circ} \mathrm{C}$ and purified through a Micro Bio-Spin p-30 column (Bio- 
Rad) according to the manufacturer's instructions. RNA was incubated with $1.5 \mu \mathrm{L}$ of T4 polynucleotide kinase (New England Biolabs) for $1 \mathrm{~h}$ at $37^{\circ} \mathrm{C}$ and then with an additional $1 \mu \mathrm{L}$ for $1 \mathrm{~h}$ more. RNA was denatured for $5 \mathrm{~min}$ at $65^{\circ} \mathrm{C}$.

Anti-BrU agarose beads (Santa Cruz Biotechnology) were rotated for $1 \mathrm{~h}$ in blocking buffer $(0.5 \times$ SSPE, $1 \mathrm{mM}$ EDTA, $0.05 \%$ Tween-20, 0.1\% PVP, $1 \mathrm{mg} / \mathrm{mL}$ BSA). Run-on RNA was rotated with beads for $1 \mathrm{~h}$, followed by 5 -min washes twice in binding buffer $(0.5 \times$ SSPE, $1 \mathrm{mM}$ EDTA, $0.05 \%$ Tween-20), twice in lowsalt buffer $(0.2 \times$ SSPE, $1 \mathrm{mM}$ EDTA, $0.05 \%$ Tween-20), once in high-salt buffer $(0.5 \times$ SSPE, $1 \mathrm{mM}$ EDTA, $0.05 \%$ Tween-20, $150 \mathrm{mM} \mathrm{NaCl}$ ), and twice in TET buffer (TE at $\mathrm{pH} 7.4,0.05 \%$ Tween-20). BrU-labeled RNA was eluted from the beads four times for 15 min with $100 \mu \mathrm{L}$ of elution buffer preheated to $42^{\circ} \mathrm{C}$. RNA was ethanol-precipitated overnight.

The RNA pellet was resuspended in water, denatured, and treated with poly(A)-polymerase (New England Biolabs) for $30 \mathrm{~min}$ at $37^{\circ} \mathrm{C}$. cDNA synthesis was performed as described previously (Wang et al. 2011) using the oNTI223 primer (5'-pGA TCGTCGGACTGTAGAACTCT;CAAGCAGAAGACGGCATA CGATTTTTTTTTTTTTTTTTTTTVN-3"), where " $\mathrm{p}$ " represents 5' phosphorylation, ";" represents the abasic dSpacer furan, and "VN" represents degenerate nucleotides. The reaction was treated with $3 \mu \mathrm{L}$ of exonuclease I (Fermentas) for $15 \mathrm{~min}$ at $37^{\circ} \mathrm{C}$ followed by $2 \mu \mathrm{L}$ of $1 \mathrm{M} \mathrm{NaOH}$ for $20 \mathrm{~min}$ at $98^{\circ} \mathrm{C}$ and neutralized with $1 \mu \mathrm{L}$ of $2 \mathrm{M} \mathrm{HCl}$. cDNA was run on a $10 \%$ TBE-urea gel, and products were excised and eluted from shredded gel pieces for $4 \mathrm{~h}$ in TE $+0.1 \%$ Tween and precipitated in ethanol overnight.

First strand cDNA was circularized for $1 \mathrm{~h}$ with CircLigase (Epicentre), denatured for $10 \mathrm{~min}$ at $80^{\circ} \mathrm{C}$, and relinearized with APE I (New England Biolabs). Relinearized DNA was PCRamplified using the Phusion Hot Start II kit, according to the manufacturer's instructions, with the primers oNTI200 (5'CAAGCAGAAGACGGCATA-3') and oNTI201 (5'-AATGAT ACGGCGACCACCGACAGGTTCAGAGTTCTACAGTCCG ACG-3'). The PCR product was run on a $10 \%$ TBE gel and eluted as in the previous step. Libraries were sequenced on an Illumina hiSeq2000 with sequencing primer 5'-CGACAGGTTCAGAGTTCT ACAGTCCGACGATC-3'.

\section{Transfection}

For PPAR $\gamma$ siRNA knockdown, mature differentiated 3T3-L1 adipocytes were electroporated using Amaxa Cell Line L (program A-033, Lonza). One-quarter of a 10-cm dish of cells was treated with 200 pmol of siRNA (sequences in Supplemental Table S3) and plated onto one well of a 12-well dish. Cells were harvested 24-30 h post-transfection.

\section{ChIP-seq}

ChIP was performed as described previously (Steger et al. 2008). The following antibodies were used in this study: C/EBP $\alpha$ (sc61x, Santa Cruz Biotechnology), C/EBP (sc-150x, Santa Cruz Biotechnology), FOSL2 (sc-13017x, Santa Cruz Biotechnology), JUND (sc-74x, Santa Cruz Biotechnology), ATF2 (sc-6233x, Santa Cruz Biotechnology), MED1 (A300-793A, Bethyl Laboratories), H3K27ac (ab4729, Abcam), CBP (sc-369x, Santa Cruz Biotechnology), p300 (sc-585x, Santa Cruz Biotechnology), and NCoR (rabbit polyclonal, generated in our laboratory). Primer sequences used for ChIP-qPCR are provided in Supplemental Table S2. ChIP DNA was prepared for sequencing according to the amplification protocol provided by Illumina. Next-generation sequencing of ChIPseq libraries was performed by the Functional Genomics Core at the University of Pennsylvania, including preprocessing and alignment of the raw tags.

\section{GRO-seq data processing}

First, adapter and poly-A sequences were trimmed off from the raw tags, and remaining tags were converted into FASTA format before alignment. Trimmed tags were aligned to the mouse genome mm8 using Bowtie (Langmead et al. 2009) with the following options: Inputs were in FASTA format $(-\mathrm{f})$, three mismatches were allowed for each tag (-v 3), and only uniquely mapped tags were retained $(-\mathrm{m} \mathrm{1)}$. All of the alignments were adjusted to 50 base pairs (bp) by extending toward the $3^{\prime}$ end if their size was shorter than that to make libraries comparable. For the visualization of GRO-seq data, we pooled two replicates for each time point and extended each tag to $150 \mathrm{bp}$ to make smooth profiles. bedGraph files were generated first using genomeCoverageBed command in the BEDTools suite (Quinlan and Hall 2010) for plus and minus strands separately and were converted to bigwig format using the bedGraphToBigWig command in BLAT suite (Kent et al. 2010). All of the microarray and high-throughput sequencing data have been deposited in Gene Expression Omnibus under the accession number GSE56747.

\section{ChIP-seq data processing}

All of the ChIP-seq tags for C/EBP $\alpha, \mathrm{C} / \mathrm{EBP} \beta$, FOSL2, ATF2, JUND, NCoR, and MED1 were aligned to mouse genome mm8 using Bowtie with options "-k 1 -m 1-best -strata," and all of the redundant tags were eliminated except one before downstream analysis. For PPAR $\gamma$, we used two public PPAR $\gamma$ ChIP-seq data, GSM340799 and GSM678393 (Nielsen et al. 2008; Schmidt et al. 2011) from Gene Expression Omnibus, where all of the redundant tags were eliminated in each data set, and the remaining tags were pooled into a single data set. Peak calling was performed using the findPeaks command in Homer (Heinz et al. 2010). After initial calling, all of the peaks were resized to $200 \mathrm{bp}$; the 2 reads per million (RPM) cutoff was applied for C/EBP $\alpha, C / E B P \beta$, FOSL2, ATF2, JUND, and PPAR $\gamma$ to select strong peaks; and the 1 RPM cutoff was applied for MED1, CBP, p300, and NCoR because of their indirect genomic binding.

\section{Gene transcription analysis}

To determine rosi-induced regulation of gene transcription, we used normalized tag counts within a window between $+0.5 \mathrm{~kb}$ and $12 \mathrm{~kb}$ of the TSS to capture acute changes and yet minimize the bias from paused signal at promoters. When counting tags, we ignored the tags aligned onto rRNA, small nucleolar RNA (snoRNA), small nuclear RNA (snRNA), or tRNA to avoid any false contribution to gene body GRO-seq signal due to these highly abundant elements. To identify rosi-regulated genes, we performed an exact test with edgeR package (Robinson et al. 2010) for each time point-10 $\mathrm{min}, 30 \mathrm{~min}, 1 \mathrm{~h}$, and $3 \mathrm{~h}-$ using $0 \mathrm{~min}$ as a control. Genes were considered rosi-regulated if the false discover rate (FDR) was $<0.05$ at any time point, but those with low GRO-seq signal $(<0.5$ RPKM [reads per kilobase per million]) or poor gene body coverage $(<70 \%)$ at every time point were discarded before downstream analysis. Temporal patterns of rosi-induced regulation were graphically presented by hierarchical clustering, where GRO-seq levels were RPKM-normalized and 1 - (correlation coefficient) was used as a distance measure between genes. The initial dendrogram was first created based on Ward's criterion using the fastcluster R package (http://danifold. net/fastcluster.html) and then subjected to optimal leaf ordering (Bar-Joseph et al. 2001). In the visualization of clustering heat maps, RPKM values were converted into $\log _{2}$ (fold change over $0 \mathrm{~min}$ ) for intuitive color representation of up-regulation or downregulation. Gene ontology analysis was performed using DAVID (Huang et al. 2008), and top ranked GO FAT terms were presented. 
Step et al.

\section{eRNA analysis}

For eRNA analysis, we defined an enhancer as an intergenic center of a bidirectional transcript. After pooling both replicates to improve transcript coverage for each time point, we identified all of the putative transcripts in plus and minus strands using the findPeaks command in Homer. Two start sites of a plus transcript and a minus transcript were paired together if their distance was $<1 \mathrm{~kb}$, and then their midpoint was defined as a center of a bidirectional transcript. Any of these centers were discarded if they are located within $2 \mathrm{~kb}$ from RefSeq genes or Satellite regions to avoid potential bias from gene body transcripts or abundant signal from Satellite regions. To investigate rosi-induced eRNA regulation, we used a pipeline similar to the gene transcript analysis with the following differences. When counting tags for eRNA, we considered a 2-kb window only around the previously defined enhancer and summed plus and minus tags. A coverage cutoff was not applied, yet the 0.5 RPKM cutoff was still applied. Among eRNAs that passed the cutoff, those with a FDR of $<0.05$ were considered rosi-regulated, and the others were considered nonregulated. For the clustering analysis, we used $\log _{2}$ (fold change over untreated) in each time point and Euclidean distance. The initial dendrogram was created by Ward's criterion and then further subjected to optimal leaf ordering. A de novo motif search was performed using Homer more than once for a given set of genomic loci, and the consensus motifs were considered for downstream analysis only if they appeared consistently with a significant $P$-value.

\section{Acknowledgments}

We thank members of the Lazar laboratory for helpful discussions and reagents, and Klaus Kaestner for critically reading the manuscript. We also thank Leighton Core, John Lis, Minna Kaikkonen, and Chris Glass for help with the GRO-seq protocol; Fang Chen and Don Baldwin for performing the microarrays; and the Functional Genomics Core of the Penn Diabetes Center (DK19525) for deep sequencing. A.P. was supported by a GEN-AU mobility grant from the Austrian Ministry of Science and Research. This work was also supported by National Institutes of Health grants R01 DK49780 (to M.A.L.), R21DK098769 (to K.-J.W.), and 5T32GM008076 (to S.E.S.) and the JPB Foundation.

\section{References}

Ahmadian M, Suh JM, Hah N, Liddle C, Atkins AR, Downes M, Evans RM. 2013. PPAR $\gamma$ signaling and metabolism: the good, the bad and the future. Nat Med 19: 557-566.

Bar-Joseph Z, Gifford DK, Jaakkola TS. 2001. Fast optimal leaf ordering for hierarchical clustering. Bioinformatics 17: S22-S29.

Bugge A, Grontved L, Aagaard MM, Borup R, Mandrup S. 2009. The PPAR 2 A/B-domain plays a gene-specific role in transactivation and cofactor recruitment. Methods Enzymol 23: 794-808.

Chao L, Marcus-Samuels B, Mason MM, Moitra J, Vinson C, Arioglu E, Gavrilova O, Reitman ML. 2000. Adipose tissue is required for the antidiabetic, but not for the hypolipidemic, effect of thiazolidinediones. J Clin Invest 106: 1221-1228.

Chawla A, Lazar MA. 1994. Peroxisome proliferator and retinoid signaling pathways co-regulate preadipocyte phenotype and survival. Proc Natl Acad Sci 91: 1786-1790.

Choi JH, Banks AS, Estall JL, Kajimura S, Bostrom P, Laznik D, Ruas JL, Chalmers MJ, Kamenecka TM, Bluher M, et al. 2010. Anti-diabetic drugs inhibit obesity-linked phosphorylation of PPAR $\gamma$ by Cdk5. Nature 466: 451-456.
Core LJ, Waterfall JJ, Lis JT. 2008. Nascent RNA sequencing reveals widespread pausing and divergent initiation at human promoters. Science 322: 1845-1848.

De Santa F, Barozzi I, Mietton F, Ghisletti S, Polletti S, Tusi BK, Muller H, Ragoussis J, Wei CL, Natoli G. 2010. A large fraction of extragenic RNA pol II transcription sites overlap enhancers. PLoS Biol 8: e1000384.

Fronsdal K, Engedal N, Slagsvold T, Saatcioglu F. 1998. CREB binding protein is a coactivator for the androgen receptor and mediates cross-talk with AP-1. I Biol Chem 273: 3185331859.

Ge K, Guermah M, Yuan CX, Ito M, Wallberg AE, Spiegelman BM, Roeder RG. 2002. Transcription coactivator TRAP220 is required for PPAR 2 2-stimulated adipogenesis. Nature 417: 563-567.

Gelman L, Zhou G, Fajas L, Raspe E, Fruchart JC, Auwerx J. 1999. p300 interacts with the $\mathrm{N}$ - and C-terminal part of PPAR $\gamma 2$ in a ligand-independent and -dependent manner, respectively. I Biol Chem 274: 7681-7688.

Gill G, Ptashne M. 1988. Negative effect of the transcriptional activator GAL4. Nature 334: 721-724.

Glass CK, Rosenfeld MG. 2000. The coregulator exchange in transcriptional functions of nuclear receptors. Genes Dev 14: $121-141$

Glass CK, Saijo K. 2010. Nuclear receptor transrepression pathways that regulate inflammation in macrophages and $\mathrm{T}$ cells. Nat Rev Immunol 10: 365-376.

Haakonsson AK, Stahl Madsen M, Nielsen R, Sandelin A, Mandrup S. 2013. Acute genome-wide effects of rosiglitazone on PPAR $\gamma$ transcriptional networks in adipocytes. Methods Enzymol 27: 1536-1549.

He W, Barak Y, Hevener A, Olson P, Liao D, Le J, Nelson M, Ong E, Olefsky JM, Evans RM. 2003. Adipose-specific peroxisome proliferator-activated receptor $\gamma$ knockout causes insulin resistance in fat and liver but not in muscle. Proc Natl Acad Sci 100: 15712-15717.

He HH, Meyer CA, Chen MW, Jordan VC, Brown M, Liu XS. 2012. Differential DNase I hypersensitivity reveals factordependent chromatin dynamics. Genome Res 22: 10151025 .

Heinz S, Benner C, Spann N, Bertolino E, Lin YC, Laslo P, Cheng JX, Murre C, Singh H, Glass CK. 2010. Simple combinations of lineage-determining transcription factors prime cis-regulatory elements required for macrophage and B cell identities. Mol Cell 38: 576-589.

Hofmann C, Lorenz K, Braithwaite SS, Colca JR, Palazuk BJ, Hotamisligil GS, Spiegelman BM. 1994. Altered gene expression for tumor necrosis factor- $\alpha$ and its receptors during drug and dietary modulation of insulin resistance. Endocrinology 134: 264-270.

Huang W, Glass CK. 2010. Nuclear receptors and inflammation control: molecular mechanisms and pathophysiological relevance. Arterioscler Thromb Vasc Biol 30: 1542-1549.

Huang DW, Sherman BT, Lempicki RA. 2008. Systematic and integrative analysis of large gene lists using DAVID bioinformatics resources. Nat Protoc 4: 44-57.

Kaikkonen MU, Spann NJ, Heinz S, Romanoski CE, Allison KA, Stender JD, Chun HB, Tough DF, Prinjha RK, Benner C, et al. 2013. Remodeling of the enhancer landscape during macrophage activation is coupled to enhancer transcription. Mol Cell 51: 310-325.

Kamei Y, Xu L, Heinzel T, Torchia J, Kurokawa R, Gloss B, Lin SC, Heyman RA, Rose DW, Glass CK, et al. 1996. A $\mathrm{CBP}$ integrator complex mediates transcriptional activation and AP-1 inhibition by nuclear receptors. Cell 85: 403-414. 
Kelleher RJ, Flanagan PM, Kornberg RD. 1990. A novel mediator between activator proteins and the RNA polymerase II transcription apparatus. Cell 61: 1209-1215.

Kent WJ, Zweig AS, Barber G, Hinrichs AS, Karolchik D. 2010. BigWig and BigBed: enabling browsing of large distributed datasets. Bioinformatics 26: 2204-2207.

Kim SW, Kim HJ, Jung DJ, Lee SK, Kim YS, Kim JH, Kim TS, Lee JW. 2001. Retinoid-dependent antagonism of serum response factor transactivation mediated by transcriptional coactivator proteins. Oncogene 20: 6638-6642.

Kim TK, Hemberg M, Gray JM, Costa AM, Bear DM, Wu J, Harmin DA, Laptewicz M, Barbara-Haley K, Kuersten S, et al. 2010. Widespread transcription at neuronal activityregulated enhancers. Nature 465: 182-187.

Kung J, Henry RR. 2012. Thiazolidinedione safety. Expert Opin Drug Saf 11: 565-579.

Lam MT, Cho H, Lesch HP, Gosselin D, Heinz S, Tanaka-Oishi Y, Benner C, Kaikkonen MU, Kim AS, Kosaka M, et al. 2013. Rev-Erbs repress macrophage gene expression by inhibiting enhancer-directed transcription. Nature 498: 511-515.

Langmead B, Trapnell C, Pop M, Salzberg SL. 2009. Ultrafast and memory-efficient alignment of short DNA sequences to the human genome. Genome Biol 10: R25.

Lee YK, Dell H, Dowhan DH, Hadzopoulou-Cladaras M, Moore DD. 2000. The orphan nuclear receptor SHP inhibits hepatocyte nuclear factor 4 and retinoid $\mathrm{X}$ receptor transactivation: two mechanisms for repression. Mol Cell Biol 20: 187195.

Lefterova MI, Zhang Y, Steger DJ, Schupp M, Schug J, Cristancho A, Feng D, Zhuo D, Stoeckert CJ Jr, Liu XS, et al. 2008. PPAR $\gamma$ and C/EBP factors orchestrate adipocyte biology via adjacent binding on a genome-wide scale. Genes Dev 22: 2941-2952.

Lehmann JM, Moore LB, Smith-Oliver TA, Wilkison WO, Willson TM, Kliewer SA. 1995. An antidiabetic thiazolidinedione is a high affinity ligand for peroxisome proliferator-activated receptor $\gamma$ (PPAR $\gamma$ ). I Biol Chem 270: 12953-12956.

Li Y, Lazar MA. 2002. Differential gene regulation by PPAR $\gamma$ agonist and constitutively active PPAR $\gamma 2$. Methods Enzymol 16: $1040-1048$.

Li M, Pascual G, Glass CK. 2000. Peroxisome proliferatoractivated receptor $\gamma$-dependent repression of the inducible nitric oxide synthase gene. Mol Cell Biol 20: 4699-4707.

Li W, Notani D, Ma Q, Tanasa B, Nunez E, Chen AY, Merkurjev D, Zhang J, Ohgi K, Song X, et al. 2013. Functional roles of enhancer RNAs for oestrogen-dependent transcriptional activation. Nature 498: 516-520.

Maeda N, Takahashi M, Funahashi T, Kihara S, Nishizawa H, Kishida K, Nagaretani H, Matsuda M, Komuro R, Ouchi N, et al. 2001. PPAR $\gamma$ ligands increase expression and plasma concentrations of adiponectin, an adipose-derived protein. Diabetes 50: 2094-2099.

Manna PR, Stocco DM. 2007. Crosstalk of CREB and Fos/Jun on a single cis-element: transcriptional repression of the steroidogenic acute regulatory protein gene. I Mol Endocrinol 39: $261-277$.

Melo CA, Drost I, Wijchers PJ, van de Werken $\mathrm{H}$, de Wit E, Oude Vrielink JA, Elkon R, Melo SA, Leveille N, Kalluri R, et al. 2013. eRNAs are required for p53-dependent enhancer activity and gene transcription. Mol Cell 49: 524-535.

Moyers JS, Shiyanova TL, Mehrbod F, Dunbar JD, Noblitt TW, Otto KA, Reifel-Miller A, Kharitonenkov A. 2007. Molecular determinants of FGF-21 activity-synergy and cross-talk with PPAR $\gamma$ signaling. I Cell Physiol 210: 1-6.

Nielsen R, Pedersen TA, Hagenbeek D, Moulos P, Siersbaek R, Megens E, Denissov S, Borgesen M, Francoijs KJ, Mandrup S, et al. 2008. Genome-wide profiling of PPAR $\gamma:$ RXR and RNA polymerase II occupancy reveals temporal activation of distinct metabolic pathways and changes in RXR dimer composition during adipogenesis. Genes Dev 22: 29532967.

Nolan JJ, Ludvik B, Beerdsen P, Joyce M, Olefsky J. 1994. Improvement in glucose tolerance and insulin resistance in obese subjects treated with troglitazone. N Engl J Med 331: 1188-1193.

Ohno H, Shinoda K, Spiegelman BM, Kajimura S. 2012. PPAR agonists induce a white-to-brown fat conversion through stabilization of PRDM16 protein. Cell Metab 15: 395-404.

Pascual G, Fong AL, Ogawa S, Gamliel A, Li AC, Perissi V, Rose DW, Willson TM, Rosenfeld MG, Glass CK. 2005. A SUMOylation-dependent pathway mediates transrepression of inflammatory response genes by PPAR- $\gamma$. Nature 437: 759-763.

Pascual-Garcia M, Rue L, Leon T, Julve J, Carbo JM, Matalonga J, Auer H, Celada A, Escola-Gil JC, Steffensen KR, et al. 2013. Reciprocal negative cross-talk between liver $\mathrm{X}$ receptors (LXRs) and STAT1: effects on IFN- $\gamma$-induced inflammatory responses and LXR-dependent gene expression. I Immunol 190: 6520-6532.

Quinlan AR, Hall IM. 2010. BEDTools: a flexible suite of utilities for comparing genomic features. Bioinformatics 26: 841842.

Rangwala SM, Lazar MA. 2004. Peroxisome proliferator-activated receptor $\gamma$ in diabetes and metabolism. Trends Pharmacol Sci 25: 331-336.

Rival Y, Stennevin A, Puech L, Rouquette A, Cathala C, Lestienne F, Dupont-Passelaigue E, Patoiseau JF, Wurch T, Junquero D. 2004. Human adipocyte fatty acid-binding protein $(\mathrm{aP} 2)$ gene promoter-driven reporter assay discriminates nonlipogenic peroxisome proliferator-activated receptor $\gamma$ ligands. J Pharmacol Exp Ther 311: 467-475.

Robinson MD, McCarthy DJ, Smyth GK. 2010. edgeR: a Bioconductor package for differential expression analysis of digital gene expression data. Bioinformatics 26: 139-140.

Rong JX, Klein JL, Qiu Y, Xie M, Johnson JH, Waters KM, Zhang V, Kashatus JA, Remlinger KS, Bing N, et al. 2011. Rosiglitazone induces mitochondrial biogenesis in differentiated murine $3 \mathrm{~T} 3-\mathrm{L} 1$ and $\mathrm{C} 3 \mathrm{H} / 10 \mathrm{~T} 1 / 2$ adipocytes. PPAR Res 2011: 179454.

Rosen ED, Sarraf P, Troy AE, Bradwin G, Moore K, Milstone DS, Spiegelman BM, Mortensen RM. 1999. PPAR $\gamma$ is required for the differentiation of adipose tissue in vivo and in vitro. Mol Cell 4: 611-617.

Schimke RT, Doyle D. 1970. Control of enzyme levels in animal tissues. Annu Rev Biochem 39: 929-976.

Schmidt SF, Jorgensen M, Chen Y, Nielsen R, Sandelin A, Mandrup S. 2011. Cross species comparison of C/EBP $\alpha$ and $\operatorname{PPAR} \gamma$ profiles in mouse and human adipocytes reveals interdependent retention of binding sites. BMC Genomics 12: 152 .

Sears DD, Hsiao A, Ofrecio JM, Chapman J, He W, Olefsky JM. 2007. Selective modulation of promoter recruitment and transcriptional activity of PPAR $\gamma$. Biochem Biophys Res Commun 364: 515-521.

Spiegelman BM, Green H. 1980. Control of specific protein biosynthesis during the adipose conversion of 3T3 cells. J Biol Chem 255: 8811-8818.

Steger DI, Lefterova MI, Ying L, Stonestrom AJ, Schupp M, Zhuo D, Vakoc AL, Kim JE, Chen J, Lazar MA, et al. 2008. DOT1L/ KMT4 recruitment and H3K79 methylation are ubiquitously coupled with gene transcription in mammalian cells. Mol Cell Biol 28: 2825-2839. 
Step et al.

Steppan CM, Bailey ST, Bhat S, Brown EJ, Banerjee RR, Wright CM, Patel HR, Ahima RS, Lazar MA. 2001. The hormone resistin links obesity to diabetes. Nature 409: 307-312.

Tontonoz P, Hu E, Graves RA, Budavari AI, Spiegelman BM. 1994a. mPPAR $\gamma 2$ : tissue-specific regulator of an adipocyte enhancer. Genes Dev 8: 1224-1234.

Tontonoz P, Hu E, Spiegelman BM. 1994b. Stimulation of adipogenesis in fibroblasts by PPAR $\gamma 2$, a lipid-activated transcription factor. Cell 79: 1147-1156.

Vernochet C, Peres SB, Davis KE, McDonald ME, Qiang L, Wang $\mathrm{H}$, Scherer PE, Farmer SR. 2009. C/EBP $\alpha$ and the corepressors $\mathrm{CtBP} 1$ and $\mathrm{CtBP} 2$ regulate repression of select visceral white adipose genes during induction of the brown phenotype in white adipocytes by peroxisome proliferator-activated receptor $\gamma$ agonists. Mol Cell Biol 29: 4714-4728.

Wang D, Garcia-Bassets I, Benner C, Li W, Su X, Zhou Y, Qiu J, Liu W, Kaikkonen MU, Ohgi KA, et al. 2011. Reprogramming transcription by distinct classes of enhancers functionally defined by eRNA. Nature 474: 390-394.

Westin S, Kurokawa R, Nolte RT, Wisely GB, McInerney EM, Rose DW, Milburn MV, Rosenfeld MG, Glass CK. 1998. Interactions controlling the assembly of nuclear-receptor heterodimers and co-activators. Nature 395: 199-202.

Wrann CD, Eguchi J, Bozec A, Xu Z, Mikkelsen T, Gimble J, Nave H, Wagner EF, Ong SE, Rosen ED. 2012. FOSL2 promotes leptin gene expression in human and mouse adipocytes. J Clin Invest 122: 1010-1021.

Yang Q, Graham TE, Mody N, Preitner F, Peroni OD, Zabolotny JM, Kotani K, Quadro L, Kahn BB. 2005. Serum retinol binding protein 4 contributes to insulin resistance in obesity and type 2 diabetes. Nature 436: 356-362.

Zhang Z, Teng CT. 2001. Estrogen receptor $\alpha$ and estrogen receptor-related receptor $\alpha 1$ compete for binding and coactivator. Mol Cell Endocrinol 172: 223-233. 


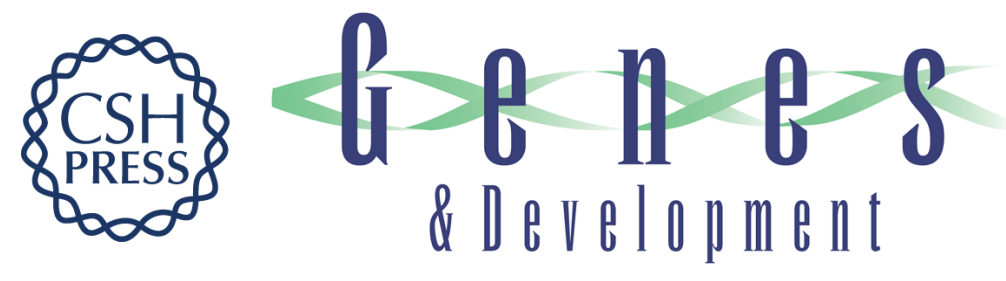

\title{
Anti-diabetic rosiglitazone remodels the adipocyte transcriptome by redistributing transcription to PPAR $\gamma$-driven enhancers
}

\author{
Sonia E. Step, Hee-Woong Lim, Jill M. Marinis, et al.
}

Genes Dev. 2014, 28:

Access the most recent version at doi:10.1101/gad.237628.114

\section{Supplemental http://genesdev.cshlp.org/content/suppl/2014/04/29/28.9.1018.DC1 Material}

References This article cites 65 articles, 21 of which can be accessed free at: http://genesdev.cshlp.org/content/28/9/1018.full.html\#ref-list-1

Creative This article is distributed exclusively by Cold Spring Harbor Laboratory Press for the first Commons six months after the full-issue publication date (see

License http://genesdev.cshlp.org/site/misc/terms.xhtml). After six months, it is available under a Creative Commons License (Attribution-NonCommercial 4.0 International), as described at http://creativecommons.org/licenses/by-nc/4.0/.

Email Alerting Receive free email alerts when new articles cite this article - sign up in the box at the top Service right corner of the article or click here.

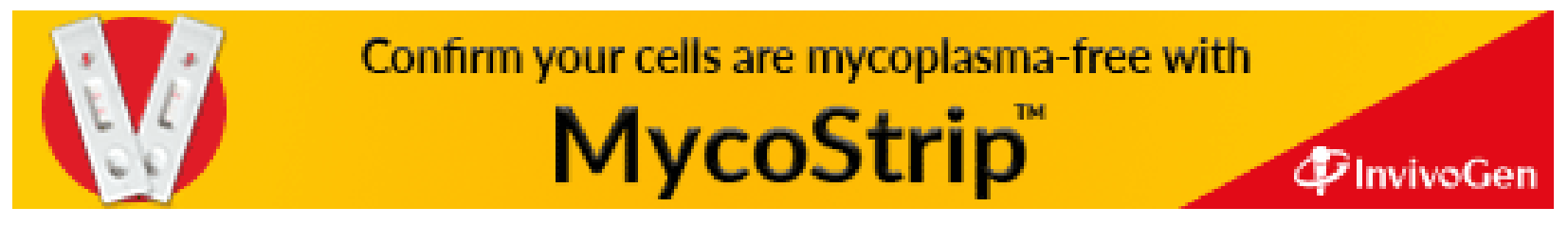

